\title{
MODIFICATION OF FOODSTUFFS: VARIABILITY OF APPROACHES AND PRIORITIES
}

\author{
G. Simakhina, R. Naumenko \\ National University of Food Technologies
}

\begin{tabular}{l}
\multicolumn{1}{c}{ Key words: } \\
Chemical composition \\
Sensory characteristics \\
Foodstuffs for well-being \\
Modification \\
Quality of life \\
\hline
\end{tabular}

Article history:

Received 08.11.2018

Received in revised form

29.11.2018

Accepted 20.12.2018

Corresponding author:

G. Simakhina

E-mail:

npnuht@ukr.net

\begin{abstract}
The scientific and practical specifications of contemporary food industry, particularly industry of products for wellbeing as its principally new sphere, are that the products obtained and destined for consumption must correspond to the main principles of the 21 st century nutrition - quality, safety and effectiveness. This is because it is aimed at health protection for people, increasing the quality of life, and achieving the active longevity.

Food and procession industry in Ukraine are obliged to provide the people with high-quality foodstuffs obtained by scientifically proved norms, first of all with optimal content of micronutrients (vitamins, mineral elements, etc.). The main sources of these substances are various raw materials: fruit and berries (wild or cultivated), vegetables, cereals, curative plants and so on. Hence, the reasonable methods to process it and furthermore to benefit the high biological value of ready-to-eat products throughout the year are to be paid the proper attention.

This task is quite complicated and diverse, regarding the wide species array of the raw materials, dependence of harvest capacity on the level of harvest (which is defined mostly by meteorological conditions, especially during blossoming, the diversity of methods to process the raw, and some other factors). It is also necessary to study the dynamics of chemical composition of vegetables, fruit and berries throughout their vegetative period in order to define the optimal terms to gather them. Upon orientation on the world experience in production of foodstuffs for well-being, the specialists constantly control the question of improvement of technological processes and elaboration of new recipes for foodstuffs within the conditions of insistent changes of consumer's requirements and the achievements of technological progress. The targeted shifts in chemical composition and sensory indices of traditional foodstuffs, achieved by different ways of modification, make possible solving each of the aforesaid tasks. The materials of this article evidence that fact.
\end{abstract}




\title{
МОДИФІКАЦІЯ ХАРЧОВИХ ПРОДУКТІВ: БАГАТОВАРІАНТНІСТЬ ПІДХОДІВ ТА ПРІОРИТЕТИ
}

\author{
Г.О. Сімахіна, Р.Ю. Науменко \\ Національний університет харчових технологій
}

Своєрідність сучасної харчової промисловості, особливо ї̈ принцииово нової сфери - індустрії здорового харчування - як науки і практики полягає в тому, що отримана і призначена для спожсивання продукція має відповідати основним принципам ХХІ століття - якість, ефективність та безпека, оскільки вона орієнтована на збереження здоров'я населення, підвищення якості життя, досягнення активного творчого довголіття.

Переробна та харчова промисловість України зобов'язані забезпечити населення високоякісними харчовими продуктами за науково обгрунтованими нормами, передусім з оптимальним вмістом мікронутрієнтів - вітамінів, мінеральних елементів тощо. Головним джерелом иих сполук $\epsilon$ сировина: плодово-ягідна (дикоросла та культивована), овочева, зернова, лікарські рослини тощо. Тому рачіональним способом ї̈ перероблення, які забезпечують високу біологічну иінність продукиї впродовж року, необхідно приділяти першочергову увагу.

Завдання щее складне та об'ємне, якщзо врахувати широкий видовий склад сировини, залежність обсягу заготівель від врожайності, яка визначається головним чином метеорологічними умовами (особливо в період иявітіння), багатоманітністю технологічних способів оброблення та іншими чинниками. Необхідно також вивчати динаміку хімічного складу овочів, плодів, ягід впродовж вегетаиійного періоду для визначення оптимальних термінів їх збору. Маючи за орієнтир світовий досвід виробнищтва продукиї для здорового харчування, фахівиі постійно тримають у полі зору питання удосконалення технологічних процесів, розроблення нових рецептур продуктів в умовах постійної зміни вимог споживачів та досягнень науково-технічного прогресу. Цілеспрямована зміна хімічного складу та сенсорних показників традиційних харчових продуктів за допомогою різних способів модифікаиіі дає можливість вирішити кожне із циих завдань, про щзо свідчать матеріали uฺiє̈ стаmmi.

Ключові слова: хімічний склад, сенсорні характеристики, оздоровчі продукти, модифікаиія, якість життя.

Постановка проблеми. Продукція сучасної харчової промисловості стала важливою складовою підтримання і збереження здоров'я людини. Враховуючи вплив біокомпонентів харчових продуктів на функціонування живого організму, можна стверджувати, що вони переважаючим чином визначають його інтелектуальну та виробничу діяльність, стан здоров'я та якість життя.

Наука про харчування стрімко розвивається, постійно продукуючи нові концепції, поглиблено вивчаючи об'єкти дослідження, періодично змінюючи, спростовуючи одні парадигми і висуваючи нові. Таким чином здійснюється 
прогрес у нутриціології, передусім у тій сфері, яка з'ясовує вплив харчування на стан здоров'я людини і привносить нові об'єктивні дані щодо нерозривного триєдиного зв'язку «людина-харчування-здоров'я».

На цьому грунті знань цілком логічно стало формування і розвиток нового напряму нутриціології, фармаконутриціології, підкреслюючи цим взаємозумовленість здоров'я і харчування. Центральна проблема цієї науки пов'язана із порушенням роботи усіх систем організму людини при розбалансуванні харчового раціону, вираженого дефіциту тих чи інших нутрієнтів, а також екстремальних зовнішніх впливах. Остання позиція особливо чітко простежується при аналізі стану здоров'я учасників АТО [1].

Аналіз останніх досліджень і публікацій. Розв'язання цієї проблеми вбачається у двох варіантах з єдиним об'єднуючим центром - здоров'я людини. Один із них включає суто медичні аспекти, які ми в даній статті не розглядаємо, а інший фокусується на проблемах розроблення, виробництва та ефективного просування на вітчизняний ринок оздоровчих продуктів різного функціонального спрямування як необхідної умови поліпшення структури та якості харчування населення в сучасному несприятливому екологічному довкіллі.

У наш час харчові продукти перестали розглядати лише як засоби поповнення організму енергією та пластичними матеріалами. Масштабні дослідження, виконані в другій половині минулого століття, показали [2], що всі біологічно активні речовини (БАР) - білки, жири, вуглеводи, вітаміни, мінеральні речовини тощо - необхідні для нормальної життєдіяльності організму, надходять переважно з їжею і засвоюються в результаті їі біотрансформації, перетравлювання та всмоктування. Перетворюючись у процесах метаболізму на структурні та функціональні елементи клітин організму, БАР забезпечують його фізичну та розумову витривалість, визначають стан здоров'я та працездатність. Нестача в раціоні тих чи тих БАР неминуче призводить до негативних наслідків.

3 цієї точки зору модифіковані певним чином продукти мають стати особливою складовою у раціонах харчування, що відрізняються від традиційної продукції своєю індивідуальною спрямованістю на поліпшення функціонування окремих органів та систем організму людини. Так, введення до рецептури продукту L-карнітину надає йому кардіопротекторних властивостей - серце цілком і повністю залежить від цієї сполуки, оскільки 70\% його енергозабезпечення надходить від жирів, котрі організм не може утилізувати без карнітину [3].

Найбільш простим і економічно вигідним шляхом вирішення зазначених завдань $є$ модифікація традиційних харчових продуктів, тобто цілеспрямована зміна їхнього хімічного складу та органолептичних властивостей із врахуванням тих специфічних характеристик, яких набувають модифіковані харчові продукти.

Метою дослідження $\epsilon$ характеристика ефективності та доцільності традиційних і нових способів модифікації харчових продуктів для визначення пріоритетних з точки зору надання продуктам оздоровчих, лікувальних та профілактичних властивостей. 
Матеріали і методи. В основу методологічної бази дослідження покладено методи наукового пізнання, узагальнення праць зарубіжних і вітчизняних учених у даному напрямі, зіставлення різних способів модифікації харчових продуктів.

Викладення основних результатів дослідження. Відповідно до Закону України «Про основні принципи та вимоги до безпечності та якості харчових продуктів» №1602-VII від 22.07.2014 [4], виробництво харчових продуктів, а значить, і їня модифікація, повинні базуватись на сучасних технологіях, принципах здорового харчування, за наявності матеріально-технічної бази, здатних забезпечити якість готової продукції за вимогами національних або міжнародних стандартів. Усі ці чинники є складовими єдиного інтегрованого виробничого процесу, орієнтованого на випуск традиційної і модифікованої продукції, на забезпечення іï якісних та конкурентоспроможних характеристик.

За класифікацією, наведеною в [5], в практичних умовах використовують такі види модифікації: сенсорну, структурно-агрегатну, генетичну, хімічну, біологічну, фізіологічну, поліфункціональну. Результати наших досліджень показали доцільність віднесення до цього переліку ще одного, найсучаснішого виду модифікації - механоактиваційного [6].

Розглянемо особливості кожного із видів модифікації з точки зору тих характеристик, яких вони надають традиційним харчовим продуктам, i які 3 них за сукупністю корисних ознак можна рекомендувати для отримання профілактичних, оздоровчих, лікувальних продуктів.

Найбільш простим і розповсюдженим видом модифікації є сенсорна, призначена для надання готовим продуктам привабливого смаку, кольору, запаху, консистенції. Особливо важливим цей вид модифікації стає при розробленні продуктів для людей з певними захворюваннями або травмами, коли чутливість сенсорних систем організму підвищується і неприємний запах чи смак можуть не лише викликати дискомфорт, а й проблеми із травною системою та погіршення стану здоров'я [7].

Разом $з$ тим слід враховувати, що модифікуючі компоненти можуть мати токсичні властивості і негативно впливати на організм людини, тому бажано для цього виду модифікації використовувати лише натуральні сполуки. Так, серед понад 500 різних штучних добавок, які використовуються в харчовій промисловості для надання продукції товарного вигляду, лише декілька можуть бути корисними для людини [8]: добавка Е 300 - вітамін С; Е 307 вітамін А; Е 101 - вітамін В ських водоростей та деякі інші. Більшість штучних добавок або індиферентні стосовно організму людини, або можуть завдавати йому шкоди. Це добавка $\mathrm{E}$ 128 - червоний барвник, має канцерогенні властивості, сприяє інвалідизації ще в зародковому стані; міститься у ковбасах та сосисках (особливо у дешевих). Це добавки Е 216 та Е 217 - консерванти, які викликають харчові отруєння; містяться у цукерках, шоколаді з начинкою, м'ясних продуктах, паштетах, супах. Це добавка Е 320 - антиоксидант, підвищує вміст « шкідливого» холестерину в крові; порушує роботу серцево-судинної системи; міститься в оліє-жирових продуктах, жувальній гумці. Особливо шкідлива 
добавка Е 951 - аспартам, цукрозамінник, викликає онкологічні захворювання головного мозку та нирок, депресії, напади паніки, здатність до самогубства та насильства. Цю добавку додають практично до всіх безалкогольних напоїв (у тому числі для дитячого харчування), жувальної гумки, кондитерських та хлібопекарських виробів.

Особливо небезпечним є введення до одного продукту декількох штучних добавок, оскільки вони можуть взаємодіяти між собою і утворювати нові токсичні, ще не вивчені сполуки.

Ще одним застереженням до використання штучних добавок при сенсорній модифікації $є$ встановлений факт, що такі добавки часто знижують або повністю нівелюють ефект корисної дії біологічно активних речовин харчових продуктів.

Таким чином, сенсорну модифікацію, особливо при виробництві харчових продуктів спеціального призначення, необхідно здійснювати лише на основі натуральних добавок, альтернативних штучним аналогам.

3 давніх часів, навіть у кустарних умовах використовували і використовують структурно-агрегатну модифікащію сировини, особливістю якої є отримання харчових продуктів у рідкому, твердому, порошкоподібному, зневодненому станах тощо. Цей вид модифікації дає можливість отримати з одного виду сировини декілька продуктів у різних агрегатних станах. Наприклад, у [9] 3 кедрових горішків отримано олію, кедрове борошно знежирене, білковий концентрат, білковий ізолят.

Найбільше суперечностей серед споживачів та й ряду учених викликає наступний вид модифікації сільськогосподарської сировини - генетична. Ї̈̈ стали використовувати з 1972 року, коли американські вчені Я. Янг та П. Байєр опублікували перші дані щодо рекомбінації молекул ДНК; потім у найбільш розвинутих країнах світу, а зараз на значній частині планети. Генна інженерія це один із напрямів, який дає можливість модифікувати сільськогосподарські культури таким чином, що їхня врожайність різко зростає, поліпшуються характеристики, збільшується кількість корисних для людини БАР [10]. Генна інженерія відрізняється від звичайної селекції тим, що комбінує генетичний матеріал різних об'єктів і отримує зовсім нові генетично модифіковані організми.

Однак щодо розвитку цього напряму модифікації, особливо у галузі харчової продукції, $\epsilon$ серйозні заперечення. Наприклад, невідомо, як буде діяти в організмі людини внесений ген; як впливатимуть генетично модифіковані організми на інші рослини чи тварини; скільки таких продуктів можна вживати без шкоди для організму тощо. І поки на ці та інші питання науковці не дадуть однозначної відповіді стосовно повної безпеки таких продуктів на основі клінічних, медико-біологічних, санітарно-гігієнічних, генетичних, мікробіологічних та інших досліджень, вважаємо, що методи генетичної модифікації впроваджувати у практику виробництва та перероблення сільськогосподарської продукції передчасно і не обгрунтовано.

Основні сфери використання хімічної модифікації - внесення штучних добрив в процесі вирощування сільськогосподарської сировини; оброблення 
хімічними препаратами плодів та овочів для подовження терміну їх зберігання; оброблення плодово-ягідної сировини розчинами кріопротекторів для підвищення iї кріорезистентності при заморожуванні; внесення хімічних сполук до напівфабрикатів для інтенсифікації технологічних процесів та надання готовим продуктам високих органолептичних характеристик тощо.

Хімічна модифікація не викликає таких побоювань, як генетична. Однак отриману продукцію теж необхідно ретельно контролювати за показниками безпеки. Адже багато харчових добавок у певних концентраціях набувають токсичних властивостей. Вони змінюють природний склад харчових продуктів, призводять до появи нових сполук, вплив яких на організм людини мало вивчено. Більш того, деякі з них віднесені до категорії небезпечних, наприклад аспартам, однак їх продовжують використовувати, завдаючи непоправної шкоди здоров'ю населення, особливо дітей і молоді.

Біологічна модифікація - одна із найдавніших за тривалістю використання при виробництві харчової продукції. Це вид модифікації, в основі якої лежить застосування одноклітинних організмів (міцеліальні гриби, дріжджі, бактерії) при отриманні хлібобулочних виробів, кисломолочних продуктів, пива, вина, соусів, приправ тощо. На відміну від хімічної модифікації харчової продукції, негативні ефекти біологічної модифікації можна повністю виключити при дотриманні усіх необхідних санітарно-гігієнічних норм в ході технологічного процесу за наявності доброякісної сільськогосподарської сировини.

Разом з тим, слід зазначити, що в сучасних умовах для посилення біохімічних реакцій у харчових технологіях можливе використання принципів генної інженерії при отриманні генетично змінених штамів мікроорганізмів. Тоді залишаються в силі всі застереження, сформульовані при розгляді особливостей генетичної модифікації харчових продуктів.

Фізіологічна модифікація є новим і надзвичайно перспективним науковопрактичним напрямом. Тому вона викликає найбільший інтерес як в межах даної теми, так і загалом в сучасних харчових технологіях. Йдеться про збагачення традиційних харчових середовищ натуральними біологічно активними речовинами та їх аналогами у концентраціях, що відповідають фізіологічним потребам організму людини, встановлених Всесвітньою організацією охорони здоров'я (ВООЗ).

Саме на основі цього виду модифікації на світовому ринку, починаючи 3 1986 року, з'явилось нове покоління харчових продуктів, яке називають здоровим, функціональним, оздоровчим харчуванням. Цей сектор світового ринку розвивається сьогодні найбільш інтенсивно, і тому фізіологічна модифікація продуктів, яка викликала справжню революцію у сфері харчових виробництв, потребує окремого розгляду.

Поліфункціональна модифікація - це істотна складова попереднього напряму. Її здійснюють шляхом використання комплексів біологічно активних речовин (вітамінів, мінеральних речовин, амінокислот тощо) як природного походження, так і їх аналогів, наприклад, у вигляді різноманітних преміксів. Це дає можливість, з одного боку, надати поліфункціональних корисних властивостей харчовим продуктам, а 3 другого - отримати з одного виду сировини 
цілий спектр харчової продукції, кожен вид якої має певну функціональну спрямованість, зумовлену комплексом БАР. Дослідження показали, що і моно-, і поліфункціональних властивостей харчовим продуктам надають біологічно активні речовини у складі рослинних комплексних збагачувачів, дієтичних добавок та натуральних біокоректорів, що ними збагачують традиційні харчові середовища.

I останній вид модифікації харчових продуктів - механоактиваційний. Він поки що не лише не набув належного розповсюдження в Україні, а й дуже мало описаний у літературі. Хоча вже з середини XX століття почав формуватись так званий четвертий компонент технології (перші три - зміни температури і тиску, механічне або хімічне диспергування, каталіз), який за 60 років розвитку переконливо довів, що він не менш важливий, ніж попередні три, особливо для харчових виробництв [11]. Цей четвертий компонент технології вчені К. Хесс, Е. Штойрер та Х. Фрамм ще в 1942 р. назвали «механічним активуванням» і таким терміном він трактується сучасною наукою.

Сутність механоактивування полягає в тому, що при такому подрібненні матеріалів і пов'язаному з цим руйнуванням часток матеріалів у них відбуваються складні зміни фізичного і хімічного стану. Зокрема, на поверхні часток утворюються дефекти, розколи, тріщини з накопиченням енергії активування. В результаті, наприклад, реакційна здатність кінцевого продукту набагато перевищує цей показник для вихідного матеріалу.

Виконані на кафедрі технології оздоровчих продуктів дослідження показали, що подрібнення сухого бурякового жому в апаратах спеціальної конструкції - дезінтеграторах з використанням ефектів механоактивування привело до істотного збільшення в отриманому модифікованому напівфабрикаті вмісту водорозчинних моносахаридів (арабінози, ксилози, глюкози) та легкогідролізованих полісахаридів у результаті розщеплення високо полімерів жому при диспергуванні [6].

До вибору способу модифікації з урахуванням тих специфічних характеристик, яких набувають модифіковані продукти і які визначаються здебільшого введенням до харчових середовищ тих чи тих компонентів, ставляться строгі вимоги.

Особливо це стосується продуктів, які позиціонуються на світовому ринку як «корисні для здоров’я». При ньому оздоровчі продукти розглядаються як соціально значущий товар, тому що він необхідний для життєзабезпечення населення України всіх вікових категорій, для підтримання продовольчої безпеки і розвитку української нації.

\section{Висновки}

Однією із особливостей модифікації харчової сировини, напівфабрикатів та продуктів $є$ іï профілізація в рамках певної галузі. Тобто модифікацію можна здійснювати в будь-якій галузі харчової промисловості, а також в закладах ресторанного господарства. Щоправда, в останньому випадку слід розраховувати на виробництво продукції обмеженої номенклатури. Разом 3 тим, така спеціалізація дає змогу невеликим підприємствам сконцентрувати увагу на розробленні, виробництві і реалізації саме тієї модифікованої про- 
дукції, яка в даний час найбільш актуальна і користується найбільшим попитом у споживачів.

Пріоритети фізіологічної, поліфункціональної, механоактиваційної, певною мірою сенсорної модифікації харчових продуктів визначаються як доведеним доказовою медициною взаємозв'язком харчування та здоров'я, так і панівним у сучасному суспільстві прагненням до здорового способу життя та підвищенням його якості, усвідомленням індивідуальної відповідальності кожного за свій фізичний та духовний стан, реалізацією способів його підтримання на належному рівні. Ці чинники, а також демографічні зміни, екологічне середовище, підвищення рівня культури харчування і зміни стереотипів харчової поведінки населення справляють суб'єктивний вплив на ринок здорової продукції, сприяючи його розвитку та розширенню. Велику роль відіграє також постійна роз'яснювальна робота 3 основних питань здорового харчування, запровадження досвіду провідних країн світу, врахування соціальних потреб різних категорій споживачів. Продуктам, які в результаті модифікації набувають певного функціонального спрямування, характерна своя специфіка, своя модель життєвого циклу, своє коло шанувальників.

Модифікація харчових продуктів розпочинається з наукової гіпотези щодо їхнього складу та призначення, яка переходить у реальне втілення теоретичних уявлень у готовий продукт; бажаним продовженням цієї роботи $є$ виробництво модифікованих харчових продуктів у промислових умовах і їх просування на ринку при відповідному маркетинговому супроводі.

\section{Лiтература}

1. Українець А.І., Сімахіна Г.О., Стеценко Н.О., Науменко Н.В., Кочубей-Литвиненко О.В. Нові продукти для раціонів військовослужбовців. Київ: Сталь, 2017. 292 с.

2. Сімахіна Г.О., Стеценко Н.О., Науменко Н.В. Біологічно активні речовини в харчових технологіях. Київ: НУХТ, 2016. 455 с.

3. Аткинс Р. Биодобавки доктора Аткинса. Пер. с англ. А. Киселева. Москва: РИПОЛ Класик, 1999. $480 \mathrm{c}$.

4. Закон України «Про основні принципи та вимоги до безпечності та якості харчових продуктів» (№1602-VII від 22.07.2014р.). URL: http://zakon2.rada/gov/ua/laws/show/771/97-80.

6. Кудряшева А.А. Секреты хорошего здоровья и активного долголетия. Москва: Пищепромиздат, $2000.320 \mathrm{c}$.

7. Сімахіна Г.О. Підвищення харчової цінності сухого бурякового жому механоактивуванням. Цукор Украӥни. 2013. № 7-8. С. 43-46.

8. Притульська Н.В., Мотузка Ю.М., Антюшко Д.П. Органолептичні властивості продуктів на сухій розчинній основі для ентерального харчування. Современные проблемы и пути их решения в науке, транспорте, производстве и образовании. Сборник научных трудов. Т. 9. Одесса, 2013. С. 82-86.

9. Ципріян В.І., Матасар I.T., Слободкін В.І. Гігієна харчування з основами нутриціології. Київ: Медицина, 2007. 544 с.

10. Субботина М.А. Исследование химического состава кедровой муки обезжиренной. Хранение и переработка сельхозсырья. 2010. №4. С. 49-50.

11. Эйзлер А.К. Европейские исследования. БАДы, витамины, ГМО, биопродукты. Как сделать правильный шаг к здоровому долголетию. Москва: Изд-во «Э», 2016. 432 с.

12. Авакумов Е.Г. Механические методы активации химических процессов. Новосибирск: Наука, 1979. 265 с. 